\title{
Pengaruh Proporsi Komisaris Independen, Jumlah Direktur, Jumlah Komite Audit, Kepemilikan Saham Institusional, Kepemilikan Saham Manajemen Dan Ukuran Perusahaan Terhadap Kinerja Keuangan Perusahaan
}

\author{
Herman Ruslim dan Ieneke Santoso \\ Fakultas Ekonomi Universitas Tarumanagara \\ Email: herman88@cbn.net.id
}

\begin{abstract}
This study aims to test the impact ofindependent commissioner, board of directors, audit committee, ownership of institutional and management shares and size of firm to the firm performance of the firms listed at Indonesian Stock Exchange Index LQ45 for two consecutive years of the period February 2014 to January 2016. This study use the sampling data of 31 firms The sampling is based on the method of purposive sampling. Process of analysis data is carried out with analysis partially first and then analysis simultaneous. The statistic method used is SPPS ( Statistical Product and Service Solution) to obtain descriptive statistics, correlation of variables and analysis of variance. The result of the partial analysis shows that there are two variable has significant influence to the firm performance which is portion of independent commissioner and ownership of institutional shares. Whereas, the result of the simultaneous analysis has shows significant impact.
\end{abstract}

\begin{abstract}
Abstrak: Penelitian ini bertujuan untuk menguji pengaruh proporsi komisaris independen, jumlah direktur, jumlah komite audit, kepemilikan saham institusional, kepemilikan saham manajemen dan ukuran perusahaan terhadap kinerja keuangan perusahaan yang terdaftar di Bursa Efek Indonesia yang termasuk dalam indeks LQ45 selama 2 tahun berturut-turut pada periode Februari 2014-Januari 2016. Penelitian ini menggunakan 31 perusahaan. Pemilihan sampel dilakukan dengan menggunakan metode purposive sampling. Proses analisis data yang dilakukan terlebih dahulu adalah pengujian secara parsialdan selanjutnya dilakukan pengujian secara simultan. Metode statistik yang digunakan adalah menggunakan program aplikasi komputer statistik yaitu Statistical Product and Service Solution (SPSS) untuk mengukur statistik deskriptif, hubungan antar variabel dan analisis varians.Hasil pengujian hipotesis secara parsial menunjukkan hanya dua variable yang berpengaruh positif secarasignifikan terhadap kinerja keuangan perusahaan yaitu variabel proporsi komisaris independen dan kepemilikan saham institusional. Hasil pengujian hipotesis secara simultan berpengaruh positif secara signifikan terhadap kinerja keuangan perusahaan secara simultan.
\end{abstract}

Keyword: firm performance, portion of independent commissioners, audit committee, ownership of institutional shares and size of firm

\section{PENDAHULUAN}

Good Corporate governance sangatlah erat dengan pendekatan keagenan, dimana sering terjadi konflik kepentingan antara manajer dan pemegang saham karenaterjadinyaperbedaaan kepentingan antara manajer dan pemegang saham dapat 
mengakibatkan timbulnya konflik yang biasa disebut agency conflict. Terjadinya krisis ekonomi pada tahun 1990 di negara negara Asia, mendasari pemerintah Indonesia membentuk Komite Nasional Kebijakan Corporate Governance (KNKCG). Muncullah inisiatif untuk menguatkan kerangka Good Corporate Governance (GCG). GCG kembali diulas dan dibenahi peraturan penerapannya (dilakukan reformasi GCG) di Indonesia ketika terjadi krisis ekonomi dunia pada tahun 1998 dan terjadinya kasus yang melibatkan perusahaan besar dan KAP ternama yaitu Enron dan Arthur Andersen.

Penelitian ini termotivasi juga dikarenakan bukti empiris mengenai pengaruh mekanisme goodcorporate goveranance terhadap kinerja keuangan perusahaan juga belum jelas dan adanya perbedaan pendapat dalam hasil penelitian.

Penelitian ini menggunakan variabel independen mekanismegoodcorporate governance yang diindikatorkan dengan proporsi komisaris independen, jumlah direktur, jumlah komite audit, kepemilikan saham institusional, kepemilikan saham manajemen dan variabel independen lainnya yaitu ukuran perusahaan. Sedangkan variabel dependen yang di pilih dalam penelitian ini adalah ROE (return on equity). Pemilihan variabel dependen ROE dalam penelitian ini dikarenakan angka ROE dapat menggambarkan berapa besar pengembalian yang didapatkan investor ketika menanamkan modalnya dalam sebuah perusahaan. ROE dalam analisa dupont dipecah menjadi 3 bagian yaitu net profit margin dikalikan dengan perputaran aset dikalikan dengan equity multiplier. Selain itu analisa dupont merupakan salah satu teknik analisa keuangan yang sifatnya menyeluruh.

Berdasarkan latar belakang diatas maka perumusan masalah penelitian ini adalah a) Apakah mekanisme good corporate governance dan ukuran perusahaan secara parsial berpengaruh terhadap kinerja keuangan perusahaan? b) Apakah mekanisme good corporate governance dan ukuran perusahaan berpengaruh terhadap kinerja keuangan perusahaan secara simultan?. Penelitian ini bertujuan untuk menguji kembali pengaruh mekanisme good corporate governance dan ukuran perusahaan terhadap kinerja keuangan perusahaan.

\section{KAJIAN TEORI}

Teori Keagenan (Agency Theory). Agency Theory atau teori keagenan pertama kali dikemukakan oleh Michael C. Jensen dan Meckling pada tahun 1976. Teori membahas hubungan antara principal dan agent. Yang dimaksud dengan principal adalah pemilik perusahaan atau pemegang saham, sedangkan agent adalah manajer perusahaan. Agency Theory mengimplikasikan adanya asimetri informasi antara manajer (agen) dengan pemilik (prinsipal). Asimetri informasi merupakan suatu keadaan dimana manajer memiliki akses informasi atas prospek perusahaan yang tidak dimiliki oleh pihak luar perusahaan.

Teori sinyal (Signalling Theory). Menurut Morris (1987) asumsi dasar signaling theory adalah masalah asimetri informasi yang terjadi dalam pasar. Teori ini menunjukkan bagaimana asimetri informasi dapat dikurangi oleh pihak yang lebih banyak memiliki informasi dengan mengirimkan sinyal kepada pihak lain. Signaling merupakan suatu gejala umum yang dapat diaplikasikan pada setiap pasar dengan asimetri informasi.

Corporate Governance. Corporate governance merupakan konsep yang didasarkan pada teori keagenan, diharapkan bisa berfungsi sebagai alat untuk memberikan keyakinan 
kepada para investor bahwa mereka akan menerima return atas dana yang telah mereka investasikan.Menurut Dani dan Hasan (2011), faktor-faktor yang mempengaruhi kinerja keuangan antara lain Good Corporate Governance (GCG). Karena prinsip-prinsip dasar dari GCG pada dasarnya memiliki tujuan untuk memberikan kemajuan terhadap kinerja keuangan pada suatu perusahaan. Semakin baik corporate governance yang dimiliki suatu perusahaan maka diharapkan semakin baik pula kinerja dari suatu perusahaan tersebut.Dalam penelitian Sabur Mollah, Omar Al Farooque dan Wares Karim (2012), menurut Shaheen dan Nishat (2005) Corporate Governance yang relatif buruk menunjukkan kinerja keuangan yang kurang menguntungkan, kurang mempunyai nilai dan kurang membayar tunai kepada pemegang sahamnya.

Komisaris Independen. Menurut Jensen dan Meckling (1976) menyatakan bahwa komisaris independen dapat bertindak sebagai penengah dalam perselisihan yang terjadi diantara para manajer internal dan mengawasi kebijakan manajemen serta memberikan nasehat kepada manajemen.Komisaris independen telah diatur dalam peraturan BEI tanggal 1 Juli 2000. Dalam peraturan itu dikemukakan bahwa perusahaan yang terdaftar di bursa harus mempunyai komisaris independen yang proporsional dengan jumlah saham yang dimiliki pemegang saham minoritas. Dalam peraturan ini persyaratan minimal komisaris independen adalah 30\% dari seluruh anggota dewan komisaris.

Direktur. Jumlah anggota direktur dianggap sebagai salah satu faktor yang mempengaruhi kinerja keuangan perusahaan tetapi tidak ada satu ukuran optimal untuk jumlah direktur. Jensen dan Meckling (1983) menunjukkan bahwa jumlah direktur yang maksimal untuk dapat berfungsi secara efektif adalah tujuh atau delapan. Namun Jensen dan Meckling (1986) juga menunjukkan bahwa jumlah direktur yang sedikit dapat meningkatan komunikasi, koordinasi dan kekompak yang akhirnya dapat membuat monitoring lebih efektif.

Komite Audit. Keberadaan komite audit di Indonesia diatur dalam Surat Edaran Bapepam Nomor SE-03/PM/2002 (bagi perusahaan publik) dan Keputusan Menteri BUMN Nomor KEP-103/MBU/2002 (bagi BUMN). Menurut Peraturan BAPEPAM Kep 29/PM/2004 tentang Peraturan Nomor IX.1.5 menyatakan bahwa komite audit terdiri dari sekurangkurangnya satu orang komisaris independen dan dua anggota lainnya berasal dari luar perusahaan.

Kepemilikan Saham Institusional. Jensen dan Meckling (1976) menyatakan bahwa kepemilikan institusional memiliki peranan yang penting dalam meminimalisasi konflik keagenan yang terjadi antara manajer dengan pemegang saham. Hal ini karena pemilik institusional ikut serta dalam pengambilan keputusan strategis sehingga mencegah tindakan manajemen laba yang dilakukan manajer.

Kepemilikan Saham Manajemen. Secara umum, manajer dapat diartikan sebagai setiap orang yang mempunyai tanggung jawab atas bawahan dan sumber daya-sumber daya organisasi lainnya (Handoko, 2003). Manajerial berarti suatu sistem yang mengatur hubungan antara manajer dengan bawahan dan sumber daya organisasi lainnya

Ukuran Perusahaan. Ukuran perusahaan adalah skala yang digunakan untuk menentukan besar kecilnya suatu perusahaan (Sari, 2012). Ukuran perusahaan dianggap mampu 
mempengaruhi kinerja perusahaan karena perusahaan besar dapat menurunkan biaya keagenan. Perusahaan besar cenderung menarik perhatian dan kemungkinan berada dalam pengamatan publik yang lebih besar dibandingkan perusahaan kecil.

Return On Equity (ROE). Menurut Mardiyanto (2009:196), Return On Equity (ROE) merupakan rasio yang digunakan untuk mengukur keberhasilan perusahaan dalam menghasilkan laba bagi pemegang saham. Apabila terjadi kenaikan dalam rasio ROE, berarti terjadi kenaikan laba bersih dari bank yang bersangkutan (Rivai dan Idroes,2007).

\section{Pengaruh proporsi komisaris independen terhadap kinerja keuangan perusahaan.} Teori keagenan menyatakan bahwa konflik kepentingan antara agent dengan principal dapat dikurangi dengan pengawasan yang tepat. Adanya dewan komisaris yang independen akan meningkatkan kualitas fungsi pengawasan dalam perusahaan. Baysinger, Kosnik, dan Turk (1991) menyatakanbahwa adanya komisaris independen tidak berpengaruh (tidak meningkatkan) terhadap kinerja perusahaan, sementara Haniffa dan Cooke (2002) menyatakan bahwa semakin besar komisaris independen dapat memberikan power kepada dewan komisaris untuk menekan manajemen untuk meningkatkan kualitas pengungkapan. Semakin besar proporsi komisaris independen menunjukkan bahwa fungsi pengawasan akan lebih baik.

Hipotesis 1 (H1): Terdapat pengaruh mekanisme good corporate governance dengan indikator proporsi komisaris independen terhadap kinerja keuangan perusahaan secara parsial.

Pengaruh jumlah direktur terhadap kinerja keuangan perusahaan. Salah satu asumsi dasar yang melandasi teori keagenan adalah asumsi tentang keorganisasian (Eisenhardt, 1989). Dalam suatu organisasi, terdapat konflik antar anggota yang mungkin timbul dan dapat memengaruhi produktivitas perusahaan dan juga arus informasi kepada pihak eksternal. Direktur dalam suatu perusahaan akan menentukan kebijakan yang akan diambil atau strategi yang akan dilakukan perusahaan baik dalam jangka pendek maupun panjang (Sam "eani, 2008). Oleh karena itu, jumlah direktur berperan dalam kinerja perusahaan dan dapat mengurangi konflik keagenan yang terjadi di perusahaan. Akan tetapi dari penelitian yang dilakukan oleh Eisenberg, Sundgren, dan Wells (1998) menunjukkan bahwa jumlah direktur menunjukkan pengaruh negatif terhadap kinerja perusahaan, sementara Dalton et al. dalam Sam "ani (2008) menyatakan bahwa jumlah direktur berhubungan positif dengan kinerja.

Hipotesis 2 (H2): Terdapat pengaruh mekanisme good corporate governance dengan indikator jumlah direktur terhadap kinerja keuangan perusahaan secara parsial.

Pengaruh jumlah komite audit terhadap kinerja keuangan perusahaan. Sam eeani (2008) menyatakan bahwa komite audit memiliki peran penting dan strategis dalam memelihara kredibilitas proses penyusunan laporan keuangan perusahaan seperti halnya menjaga berjalannya sistem pengawasan perusahaan yang memadai serta penerapan good corporate governance. Menurut Reddy et al, 2010 menyatakan bahwa kehadiran komite audit dalam entitas perusahaan publik memiliki efek positif pada pengurangan biaya keagenan ketika diukur dengan biaya terhadap pendapatan. Penelitian yang dilakukan oleh Sekaredi (2011) menunjukkan bahwa jumlah komite audit tidak berpengaruh terhadap 
kinerja keuangan, sementara menurut Xie et al. (2003) jumlah komite audit dapat meningkatkan efektivitas komite audit sehingga mampu mencegah tindakan manajemen laba dan meningkatkan kinerja perusahaan.

Hipotesis 3 (H3): Terdapat pengaruh mekanisme good corporate governance dengan indikator jumlah komite audit terhadap kinerja keuangan perusahaan secara parsial.

Pengaruh kepemilikan saham institusional terhadap kinerja keuangan perusahaan. Menurut Jensen dan Meckling (1976) kepemilikan manajerial dan institusional merupakan dua mekanisme corporate governance utama yang dapat membantu mengurangi masalah keagenan, yaitu tidak selarasnya kepentingan antara manajemen dengan pemegang saham. Penelitian yang dilakukan oleh Ndaruningpuri (2006) menghasilkan analisis bahwa secara partial investor institusional berpengaruh positif tapi tidak signifikan. Penelitian Pizarro et al (2006) dan Bjuggren et al., (2007) menemukan bahwa kepemilikan institusional berpengaruh secara positif terhadap kinerja perusahaan.

Hipotesis 4 (H4): Terdapat pengaruh mekanisme good corporate governancedengan indikator kepemilikan saham institusional terhadap kinerja keuangan perusahaan secara parsial.

Pengaruh kepemilikan saham manajemen terhadap kinerja keuangan perusahaan. Sofyaningsih dan Hardiningsih (2011) bahwa perusahaan dengan kepemilikan manajerial yang lebih tinggi memiliki kecenderungan nilai pasar saham yang lebih tinggi, yang membuktikan bahwa agency conflict bisa diatasi dengan memasukkan manajer dalam struktur kepemilikan saham.. Herawaty (2008) menyatakan bahwa kepemilikan manajerial merupakan sarana pengawasan yang efektif sehingga dapat mengurangi tindakan manajemen laba dari manajer. Penelitian yang dilakukan oleh Daniel dan Yeterina (2014) menunjukkan bahwa kepemilikan manajerial tidak berpengaruh pada kinerja bank.

Hipotesis 5 (H5): Terdapat pengaruh mekanisme good corporate governance dengan indikator kepemilikan saham manajemen terhadap kinerja keuangan perusahaan secara parsial.

Pengaruh ukuran perusahaan terhadap kinerja keuangan perusahaan. Perusahaan besar memiliki pertumbuhan yang lebih besar dibandingkan dengan perusahaan kecil, sehingga tingkat pengembalian saham perusahaan besar lebih besar dari return saham perusahaan skala kecil. Perusahaan besar mempunyai persistensi profitabilitas yang lebih besar dibandingkan dengan perusahaan yang ukurananya lebih kecil karena perusahaan besar lebih mempunyai banyak akses ke sumber daya dan akibatnnya memiliki lebih banyak fleksibilitas untuk perubahan pasar yang dinamis dalam penelitian Salman \& Yazdanfar(2012). Menurut Al-Amameh (2014) \& El-Chaarani (2014) dalam penelitiannya menunjukkan hasil yang signifikan antara ukuran perusahaan dengan kinerja perusahaan. Sedangkan dalam penelitian Nadeem Sheikh (2013), Nazli Anum (2010) menganalisis data perusahaan non keuangan yang terdaftar di bursa Malaysia dan menemukan ukuran perusahaan berhubungan negatif dengan kinerja perusahaan.

Hipotesis 6 (H6):Terdapat pengaruh ukuran perusahaan terhadap kinerja keuangan perusahaan secara parsial.

Pengaruh mekanisme good corporate governance dengan indikator porporsi komisaris, jumlah direktur, jumlah komite audit, kepemilikan saham institusional, 
kepemilikan saham manajemen dan ukuran perusahaan terhadap kinerja keuangan secara simultan. Dalam penelitian Nadeem Sheikh, 2013 menunjukkan bahwa mekanisme corporategovernance internal memiliki dampak signifikan terhadap kinerja perusahaan. Penelitian iniberlawanan dengan penelitian Nazli Anum (2010) yang menunjukkan tiada ada dampak yang signifikan variable corporate governance terhadap kinerja perusahaan yang diukur dengan Tobin-Q.Menurut Melia dan Yulius (2015) dalam penelitiannya, secara simultan dewan komisaris, komisaris independen, kepemilikan manajerial, dan ukuran perusahaan mempengaruhi kinerja perusahaan yang diukur dengan ROA.

Hipotesis 7 (H7): Terdapat pengaruh mekanisme good corporate governance dengan indikator proporsi komisaris independen, jumlah direktur, jumlah komite audit, kepemilikan saham.

\section{METODE}

Populasi dan Teknik Pemilihan Sampel. Populasi dalam penelitian ini adalah jumlah perusahaan yang terdaftar di Bursa Efek Indonesia dan masuk dalam Indeks LQ45 pada periode Februari 2014 - Januari 2016, dengan sampel sebanyak 31 perusahaan, dimana dari perusahaan tersebut datanya diambil dari laporan keuangan tahunan periode 20122015. Teknik pemilihan sampel dalam penelitian ini dipilih dengan metode purposive sampling.

Operasional Variabel dan Instrumen. Variabel yang digunakan dalam penelitian ini ada dua yaitu:

Variabel Independen (bebas). Variabel independen dalam penelitian ini adalah:

a. Proporsi Komisaris Independen, variabel ini diukur melalui proporsi jumlah komisaris independen terhadap seluruh anggota dewan komisaris. Variabel ini selanjutnya akan dilambangkan dengan KIND.

b. Jumlah direktur, variabel ini diukur dengan jumlah seluruh anggota direktur dalam perusahaan (Beiner et al., 2003). Variabel ini selanjutnya akan dilambangkan dengan DDIR.

c. Jumlah komite audit, variabel ini diukur dengan jumlah anggota komite audit yang dimiliki perusahaan.

d. Kepemilikan Saham Institusional, variabel ini diukur dengan membandingkan jumlah saham yang dimiliki oleh pemegang saham institusional terhadap total modal saham yang beredar. Variabel ini selanjutnya dilambangkan dengan KINS,

e. Kepemilikan Saham Manajemen, variabel ini diukur dengan mambandingkan jumlah saham yang dimiliki oleh pihak manajemen terhadap total modal saham yang beredar (Beiner et al., 2003). Variabel ini selanjutnya akan dilambangkan dengan KMAN.

f. Ukuran Perusahaan, variable ini diukur dengan menggunakan $\log (L N)$ total asset (ElChaarani, 2014).

Variabel Dependen (tergantung). Variabel tergantung adalah variabel yang memberikan reaksi atau respon jika dihubungkan dengan variabel bebas. (Jonathan Sarwono, 2006) .Variabel dependen penelitian ini adalah kinerja keuangan perusahaan yang diindikatorkan denganReturn On Equity (ROE).

ROE dihitung dengan menggunakan rumus sebagai berikut: 


$$
\mathbf{R O E}=\frac{\text { Laba bersih }}{\text { Total ekuitas }}
$$

Analisis Data. Teknik analisis data yang digunakan adalah teknik analisis regresi linear berganda . Pengujian ini menggunakan bantuan program aplikasi komputer statistik yaitu Statistical Product and Service Solution (SPSS).

\section{HASIL DAN PEMBAHASAN}

Hasil Statistik Deskriptif. Statistik deskriptif menunjukkan ukuran statistik seperti nilai rata-rata (mean), minimum, maksimum, standar deviasi dari variabel-variabel penelitian.

Tabel 1. Hasil Pengujian Descriptive Statistics

\begin{tabular}{lrrrrr}
\hline & N & Minimum & Maximum & \multicolumn{1}{l}{ Mean } & Std. Deviation \\
\hline ROE & 124 &, 03000 & 1,26000 &, 2092839 &, 20113802 \\
KIND & 124 &, 29000 &, 80000 &, 4358065 &, 12824073 \\
DDIR & 124 & 4,00000 & 11,00000 & 7,3629032 & 1,84494333 \\
KAUD & 124 & 2,00000 & 8,00000 & 3,6370968 & 1,07699278 \\
KINS & 124 &, 18000 &, 98000 &, 6145968 &, 14198018 \\
KMAN & 124 &, 00000 &, 16000 &, 0064516 &, 02635571 \\
UPER & 124 & 22,95000 & 34,44000 & 31,1420968 & 1,80956370 \\
Valid N & 124 & & & & \\
(listwise) & & & & & \\
\hline
\end{tabular}

Pengujian Hipotesis. Uji Statistik t. Untuk menguji H1, H2, H3, H4, H5 dan H6 digunakan uji regresi parsial. Dalam penelitian ini menggunakan tingkat signifikansi sebesar $5 \%$.

\begin{tabular}{|c|c|c|c|c|}
\hline \multirow[t]{2}{*}{ Model } & \multicolumn{2}{|c|}{ Unstandardized Coefficients } & \multirow[t]{2}{*}{$\mathrm{T}$} & \multirow[t]{2}{*}{ Sig.*) } \\
\hline & B & Std. Error & & \\
\hline 1 (Constant) & $-2,161$ &, 875 & $-2,471$ & ,015 \\
\hline KIND & 2,014 & ,412 & 4,891 & ,000 \\
\hline DDIR &,- 012 & ,033 &,- 378 & ,706 \\
\hline KAUD & ,089 & ,047 & 1,889 & 061 \\
\hline KINS & 1,512 & ,332 & 4,551 & ,000 \\
\hline KMAN & $-3,043$ & 1,819 & $-1,673$ & ,097 \\
\hline UPER &,- 053 & ,031 & $-1,732$ & 086 \\
\hline
\end{tabular}

Tabel 2. Hasil Pengujian Hipotesis t-test

a. Dependent Variable: LNROE

b. Correlation is significant at the 0.05 level

Berdasarkan Tabel 2 dapat dilihat bahwa hasil pengujian Hipotesis $\mathrm{t}$ - test hanya variabel proporsi komisaris independen (H1) dan kepemilikan saham institusional (H4) yang dalam pengujian hipotesisnya menunjukkan nilai signifikan yaitu 0,000 , maka disimpulkan 
bahwa $\mathrm{H} 1$ dan $\mathrm{H} 4$ tidak ditolak, sehingga dapat diartikan bahwa mekanisme good corporate governance dengan indikator proporsi komisaris independen dan kepemilikan saham institusional berpengaruh signifikan terhadap kinerja keuangan perusahaan secara parsial dengan arah positif. Sedangkan hasil pengujianhipotesislainnya (H2, H3, H5, H6) menunjukkan nilai signifikan diatas 0,05 maka disimpulkan bahwa H2, H3, H5 dan H6 ditolak.

Uji F (ANOVA). Hasil Test of ANOVA pada penelitian ini diperoleh nilai signifikansi 0,000 yang artinya lebih kecil dari $\alpha=0,05$. Hal ini menunjukkan secara bersamaan (simultan) proporsi komisaris independen, jumlah direktur, jumlah komite audit, kepemilikan saham institusional, kepemilikan sahammanajemen dan ukuran perusahaan memilikipengaruh signifikan terhadap kinerja keuangan perusahaan pada tingkat signifikansi $1 \%$.

Tabel 3. Hasil Pengujian Test of ANOVA

\begin{tabular}{|c|c|c|c|c|c|c|}
\hline \multicolumn{7}{|c|}{ ANOVA $^{a}$} \\
\hline Model & & Sum of Squares & Df & Mean Square & $\mathrm{F}$ & Sig. \\
\hline \multirow{3}{*}{1} & Regression & 15,764 & 6 & 2,627 & 10,483 &, $000^{b}$ \\
\hline & Residual & 29,324 & 117 &, 251 & & \\
\hline & Total & 45,088 & 123 & & & \\
\hline
\end{tabular}

a. Dependent Variable: LNROE

b. Predictors: (Constant), UPER, KINS, KIND, KMAN, KAUD, DDIR

Uji Koefisien Determinasi $\left(\mathbf{R}^{2}\right)$. Nilai Adjusted $\mathbf{R}^{2}$ pada tabel diatas sebesar 0,316 artinya besarnya variasi-variasi dari variabel kinerja keuangan perusahaan (variabel dependen) yang dapat dijelaskan oleh variabel proporsi komisaris independen, jumlah direktur, jumlah komite audit, kepemilikan saham institusional, kepemilikan saham manajemen dan ukuran perusahaan (variabel independen) adalah sebesar 31,6\% dan sisanya 68.4\% (100\%$31,6 \%$ ) dijelaskan oleh faktor faktor lain yang tidak dijelaskan dalam model regresi ini.

Tabel 4. Hasil Pengujian Uji $\mathrm{R}^{2}$ dan Adjusted $\mathrm{R}^{2}$

\begin{tabular}{cccc}
\hline Model & R Square & Adjusted R Square & $\begin{array}{c}\text { Std. Error of the } \\
\text { Estimate }\end{array}$ \\
\hline 1 &, 350 &, 316 &, 50063061 \\
\hline
\end{tabular}

Analisa Regresi Berganda. Berikut ini akan disajikan model persamaan regresi berganda variabel proporsi komisaris independen $\left(\mathrm{X}_{1}\right)$, jumlah direktur $\left(\mathrm{X}_{2}\right)$, ukuran komite audit $\left(X_{3}\right)$, kepemilikan saham institusional $\left(X_{4}\right)$, kepemilikan saham manajemen $\left(X_{5}\right)$ dan ukuran perusahaan $\left(\mathrm{X}_{6}\right)$ dengan varibel kinerja keuangan perusahaan $(\mathrm{Y})$

$\mathrm{Y}_{\mathrm{LN} \mathrm{ROE}}=-2,161+2,014 \mathrm{X}_{1}-0,012 \mathrm{X}_{2}+0,089 \mathrm{X}_{3}+1,512 \mathrm{X}_{4}-3,043 \mathrm{X}_{5}-0,053 \mathrm{X}_{6}+\mathrm{e}$

Pembahasan. Hasil uji hipotesis pertama (HI) menyimpulkan bahwa mekanisme good corporate governance dengan indikator proporsi komisaris independen berpengaruh signifikan terhadap kinerja keuangan perusahaan secara parsial dengan arah positif.Hasil 
penelitian ini mendukung penelitian Herawaty (2008) yang menemukan bahwa komisaris independen sebagai variabel moderating dari earning manajemen berpengaruh signifikan terhadap nilai perusahaan. Namun hal ini berlawanan dengan hasil penelitian Ndaruningpuri (2006) dan Abdul Karim yang hasil penelitiannya adalah proporsi dewan komisaris independen tidak signifikan berpengaruh terhadap kinerja perusahaan.

Hasil uji hipotesiskedua (H2) menyimpulkan bahwamekanisme good corporate governancedengan indikator jumlah direktur tidak berpengaruh signifikan terhadap kinerja keuangan perusahaan secara parsial dengan arah negatif. Penelitian lain yang tidak sejalan dengan hasil penelitian ini yaitu Daniel dan Yeterina (2014) dengan hasil penelitian yang menyatakan jumlah direktur berpengaruh positif terhadap kinerja bank. Nadeem Sheikh (2013), dalam penelitiannya yang menyatakan jumlah direktur berhubungan positif dan signifikan terhadap kinerja perusahaan. Teori ketergantungan sumber daya (resource dependency theory) juga mendukung pendapat bahwa jumlah direktur yang lebih besar dapat memberikan nilai perusahaan yang lebih tinggi.

Hasil penelitian ini mengindikasikan banyak perusahaan di Indonesia yang dimiliki oleh grup atau keluarga besar sehingga pemilihan anggota direktur seringnya berdasarkan kekeluargaan atau kekerabatan dan direktur merupakan kepanjangan tangan dari pemegang saham mayoritas. Hal ini mengakibatkan direktur tidak dapat menjalankan tugas dan tanggung jawabnya secara leluasa termasuk dalam hal mengambil keputusan, kebijakan yang bersifat strategis, sehingga dapat dikatakan bahwa keberadaan direktur kurang memiliki pengaruh dalam kinerja keuangan perusahaan.

Hasil uji hipotesis ketiga (H3) menyimpulkan bahwa tidak ada pengaruh signifikan mekanisme good corporate governance dengan indikator jumlah komite audit terhadap kinerja keuangan perusahaan secara parsial dengan arah positif. Dalam penelitian Abdul Basyith, Fitriya Fauzi dan Muhammad Idris (2015) variabel komite audit tidak berpengaruh signifikan dan negatif terhadap kinerja perusahaan. Namun sebaliknya pada penelitian Tumpal Manik(2011) bahwa komite audit berpengaruh signifikan terhadap terhadap kinerja perusahaan. Hasil penelitian ini mengindikasi karena adanya pemahaman akan fungsi, tugas dan tanggung jawab komite audit yang masih bervariasi, sehingga memicu komite audit menjadi tidak efektif dalam menjalankan tugas yang pada akhirnya dapat menyebabkan tidak terwujudnya kualitas kinerja perusahaan, disamping itu di Indonesia masih banyak perusahaan yang komite auditnya tidak hanya bekerja pada satu perusahaan melainkan bekerja pada beberapa perusahaan, komunikasi antara komisaris dan komite audit tidak berjalan harmonis serta kurangnya pantauan lembaga Pemerintah terhadap standar profesi komite audit sehingga mengakibatkan komite audit tidak dapat bekerja secara efisien dan efektif.

Hasil uji hipotesis keempat (H4) menyimpulkan bahwa mekanisme good corporate governance dengan indikator kepemilikan saham institusional berpengaruh signifikan terhadap kinerja keuangan perusahaan secara parsial dengan arah positif. Penelitian Daniel dan Yeterina (2014) yang menyatakan kepemilikan institusi berpengaruh signifikan negatif terhadap kinerja keuangan perbankan, namun berbeda dengan, begitu pula dengan penelitian Ndaruningpuri (2006) menyatakan bahwa kepemilikan institusi tidak signifikan positif berpengaruh terhadap kinerja perusahaaan, hal ini menunjukkan bahwa pemilik mayoritas institusi ikut dalam pengendalian perusahaan namun bertindak untuk kepentingan mereka sendiri meskipun dengan mengorbankan kepentingan pemilik minoritas. 
Hasil uji hipotesis kelima (H5) menyimpulkan bahwa mekanisme good corporate governance dengan indikator kepemilikan saham manajemen tidak berpengaruh signifikan terhadap kinerja keuangan perusahaan secara parsial dengan arah negatif. Dalam penelitian Nazli Anum (2010), Jensen dan Meckling(1976) menyatakan manajemen yang memiliki saham pada suatu perusahaan akan meningkatkan motivasi manajemen dalam meningkatkan kinerjanya yang pada akhirnya akan berdampak terhadap kinerja keuangan perusahaan. Penelitian Nazli Anum (2010) bahwa kepemilikan manajeman tidak berpengaruh signifikan terhadap kinerja perusahaan sehingga mendukung penelitian ini.

Penelitian ini mengindikasikan bahwa pengaruh kepemilikan saham manajemen tidak signifikan terhadap kinerja keuangan perusahaan karena porsi kepemilikan saham manajemen sangat rendah dalam suatu perusahaan. Dengan kepemilikan saham manajemen yang rendah, membuat manajemen hanya merupakan kepanjangan tangan dari pemilik mayoritas karena segala keputusan berada di pemegang saham mayoritas, sehingga dapat dikatakan keberadaan manajemen kurang memiliki pengaruh dalam kinerja keuangan perusahaan. Selain itu dengan rendahnya jumlah kepemilikan saham manajemen juga tidak dapat menyelaraskan kepentingan pemegang saham dan manajemen, menyebabkan manajemen kurang maksimal dalam menjalankan tugasnya untuk memaksimalkan kekayaan pemegang saham yaitu meningkatkan kinerja keuangan perusahaan.

Hasil uji hipotesis keenam (H6) menyimpulkan bahwa ukuran perusahaan tidak berpengaruh signifikan terhadap kinerja keuangan perusahaan dengan arah negatif. Penelitian Nazli Anum (2010) yang menguji 87 perusahaan non keuangan yang terdaftar pada bursa Malaysia dan menemukan bahwa ukuran perusahaan berhubungan negatif dengan kinerja perusahaan, kemungkinan hal ini terjadi karena masalah dalam mengkoordinasikan tugas dan fungsi yang berbeda pada setiap bagian kegiatan usaha perusahaan. Penelitian ini berbeda dengan penelitian dari Nadeem Sheikh (2013) yang menyatakan bahwa ukuran perusahaan berhubungan positif signifikan terhadap kinerja perusahaan, hal ini menunjukkan bahwa perusahaan besar mendapatkan manfaat ekonomi yang besar sehingga memberikan dampak yang lebih baik terhadap kinerja perusahaan.Penelitian ini mengindikasikan bahwa tidak adanya pengaruh ukuran perusahan terhadap kinerja keuangan perusahaan karenaseperti yang kita ketahui bahwa good corporate governance sangat erat berhubungan dengan kinerja keuangan perusahaan, dimana perusahaan yang menjalankan good corporate governance dengan baik akan mempunyai hasil kinerja keuangan yang baik. Namun demikian perusahaan yang mempunyai nilai aset yang besar tidak selalu menjalankan good corporate governance, sebagai contoh, telah terjadinya kasus-kasus penyimpangan seperti Enron, Worldcom, Xerox Corporation, Telkomsel yang merupakan anak perusahaan dari Telkom, Kalbe Farma, Waskita Karya, Kimia Farma, Great River dan perusahaan besar lainnya. Demikian pula dengan perusahaan yang kecil tidak selalu tidak menerapkan good corporate governance.

Hasil uji hipotesis ketujuh (H7) menyimpulkanbahwa proporsi komisaris independen, jumlah direktur, jumlah komite audit, kepemilikan saham institusional, kepemilikan saham manajemen dan ukuran perusahaan memiliki pengaruh signifikan terhadap kinerja keuangan perusahaan.Penelitian ini sejalan dengan penelitian Ndaruningpuri (2006) bahwa secara bersama sama variabel jumlah direktur, proporsi dewan komisaris independen, debt to equity dan institusional ownership berpengaruh secara signifikan dengan taraf kepercayaan 1\%. Hasil penelitian Melia dan Yulius (2015) 
menunjukkan bahwa variabel independen yaitu dewan komisaris, komisaris independen, kepemilikan manajerial dan ukuran perusahaan secara bersama-sama berpengaruh signifikan terhadap variabel dependen dengan tingkat signifikan pada tingkat $1 \%$.

\section{PENUTUP}

Simpulan. Berdasarkan pembahasan atas penelitian terhadap 31 perusahaan yang terdaftar pada Bursa Efek Indonesia dan masuk dalam indeks LQ45 selama 2 tahun secara dua tahun berturut-turut dengan data yang diambil dari laporan keuangan tahunan periode 2012-2015, maka dapat disimpulkan bahwa pengujian secara masing masing variable hanya variabel proporsi komisaris independen dan kepemilikan saham institusional yang berpengaruh signifikan dengan arah positif terhadap kinerja keuangan perusahaan. Sedangkan secara bersama-sama variabel proporsi komisaris independen, jumlah direktur, jumlah komite audit, kepemilikan saham institusional dan kepemilikan saham manajeman serta ukuran perusahaan berpengaruh signifikan terhadap kinerja keuangan perusahaan pada tingkat signifikansi $1 \%$, semua variabel memberikan kontribusi sebesar $31.6 \%$ dan sisanya $68,4 \%$ dijelaskan oleh faktor-faktor lain yang tidak dijelaskan dalam model regresi ini.

Saran. Karena keterbatasan waktu peneliti hanya meneliti 31 sampel perusahaan yang masuk dalam Indeks LQ45 yang tercatat di Bursa Efek Indonesia, penelitan selanjutnya dapat dilakukan dengan menggunakan perusahaan-perusahaan dari semua sektor usaha yang tercatat di Bursa Efek Indonesia dan menggunakan data dari periode yang lebih panjang. Penelitian selanjutnya bisa juga menggunakan sampel perusahaan yang pada Negara yang taat hukum seperti Amerika \& Eropa. Disamping itu karena terbatasnya jumlah variabel independen yang diteliti tercermin pada nilai adjusted $\mathrm{R}^{2}$ sebesar $31,6 \%$ maka penelitian selanjutnya dapat dilakukan dengan menggunakan variabel independen lainnya atau menambah jumlah variabel independen sehingga nilai adjusted $\mathrm{R}^{2}$ dapat menjadi lebih tinggi dan menggunakan variabel dependen Tobin's-q, EVA.

\section{DAFTAR RUJUKAN}

Abdul Basyith, Fitriya Fauzi, Muhammad Idris (2015), “The Impact of Board Structure and Ownership Structure on Firm Performance: An Evidence from Blue Chip Firms Listed in Indonesian Stock Exchange", Corporate Ownership \& Control, 12 (4), Summer, 344-351

Al-Amameh, A. (2014). "Corporate Governance, Ownership Structure and Bank Performance in Jordan". International Journal of Economics and Finance, 6(6), 6981.

Baysinger, B., Kosnik, R. D., \& Turk, T. A. (1991). "Effects of Board and Ownership Structure on Corporate R\&D Strategy", Academy of Management Journal, 34: 205214

Beiner, S., Drobetz, W., Schmid, F., \& Zimmermann, H. (2003). "Is Board Size An Independent Corporate Governance Mechanism?" http://www.wwz.unibas.ch /cofi/publications/papers/2003/06.03.pdf 
Bjuggren, P-O., Eklund, J. E., and Wiberg, D. (2007), “Ownership, Control and Firm Performance: The effects of vote-differentiated shares", Applied Financial Economics, 17(16), 1323-1334.

Daniel Felimanto Hartono \& Yeterina Widi Nugrahanti (2014). "Pengaruh Mekanisme Corporate Governance Terhadap Kinerja Keuangan Perusahaan Perbankan", Jurnal Dinamika Akuntansi Keuangan dan Perbankan, 3, 1-22.

Dani Riandi dan Hasan Sakti Siregar. (2011).'Pengaruh Penerapan Good CorporateGovernance terhadap ROA, NPM dan EPS pada Perusahaan yang Terdaftar diCGPI". Jurnal Ekonomi, 14 (3), 127-133

Eisenhardt, Kathleem. (1989). "Agency Theory: An Assesment and Review" , Academy of Management Review, 14, 57-74.

Eisenberg, Sundgren, Wells (1998). "Larger board size and decreasing firm value in small firms", Journal of Financial Economics 48, 35 - 54.

El-Chaarani, H. (2014). The Impact of Corporate Governance on the Performance of Lebanese Banks. The International Journal of Business and Finance Research, 8(5), 22-34.

Fitriya Fauzi and Stuart Locke (2012). "Board Structure, Ownership Structure and Firm Performance: A Study of New Zealand Listed - Firms", Asian Academy of Management Journal of Accounting and Finance, 2, 43-67.

Handoko, T. H. (2003). Manajemen Personalia dan Sumber Daya Manusia. Jogyakarta: BPFE

Haniffa, R. dan Cooke, T.E (2002). Culture, Corporate Governance and Disclosure in Malysian Corporations, Abacus 38 (3), 317-349.

Herawaty, V. (2008). "Peran Praktek Corporate Governance Sebagai Moderating Variable dari Pengaruh Earnings Management Terhadap Nilai Perusahaan", Jurnal Akuntansi dan Keuangan, 10 (2), November, 97-108.

Jensen, M. C dan Meckling, W. H. (1976). The Theory of the Firm: Managerial Agency Cost and Ownership Structures. Journal of Financial Economics. 3, 305-360.

Jensen, M. C (1983). Organisation Theory and methodology. The Accounting Review, LVIII (2), 319-333.

Jensen, M. C (1986). Agency Cost of Free Cash Flow, Corporate Finance, and Takeovers, American Economic Review, 76, 323-329.

Keputusan Mentri Badan Usaha Milik Negara Nomor: KEP-103/MBU/2002 tentang Pembentukan Komite Audit Bagi Badan Usaha Milik Negara.

Keputusan Ketua Bapepam Nomor Kep 29/PM/2004 tentang Pembentukan dan Pedoman Pelaksanaan Kerja Komite Audit, Peraturan Nomor IX.1.5

Mardiyanto, H. (2009). Intisari Manajemen Keuangan, PT Gramedia Widiasarana Indonesia (Grasindo). Jakarta.

Melia Agustina Tertius dan Yulius Jogi Christiawan (2015). "Pengaruh GoodCorporate Governanceterhadap Kinerja Perusahaan pada Sektor Keuangan", Business Accounting Review, 3 (1), 223-232.

Morris. R (1987). "Signalling, Agency Theory and Accounting Policy Choice", Accounting and Business Research, 18 (69), 47-56.

Nadeem Ahmed Sheikh, Zongjun Wang and Shoaib Khan (2013). "The impact of internal attributes of corporate governance on firm performance in Pakistan", International Journal of Commerce and Management, 23 (1), 38-55. 
Ndaruningpuri Wulandari (2006). "Pengaruh Indikator Mekanisme Corporate Governance Terhadap Kinerja Perusahaan Publik di Indonesia" Fokus Ekonomi, 1 (2), 120-136.

Nazli Anum Mohd Ghazali (2010). "Ownership Structure, Corporate Governance and Corporate Performance in Malaysia", International Journal of Commerce and Management, 20 (2), 109-119

Pizarro,V.,S.Mahenthiran, D. Cademamartori, and C. Roberto (2006). "The Influence of Insiders and Institutional Owners on the Value, Transparency, and Earnings Quality of Chilean Listed Firms". Editorial Manager (tm) for Contemporary Accounting Research Manuscript Draft, ppl-33

Reddy, K., Locke, S., \& Scrimgeour, F. (2010). "The Efficacy of Principle-Based Corporate Governance Practices and Firm Financial Performance".International Journal of Managerial Finance, 6, 190-216.

Rizkia Anggita Sari (2012). “ Pengaruh Karakteristik Perusahaan Terhadap Corporate Social Responsibility Disclosure pada Perusahaan Manufaktur yang Terdaftar di Bursa Efek Indonesia", Journal Nominal, I (I), 124-140

Rivai, Veitzhal, Andria Permata Veitzhal, dan Ferry N. Idroes. (2007). "Bank and Financial Institution M anagement" . Jakarta: PT. Raja Grafindo Persada.

Sam"ani (2008). " Pengaruh Good Corporated Governance dan Leverage terhadap Kinerja Keuangan pada Perbankan yang terdaftar di Bursa Efek Indonesia tahun 2004-2007”, Tesis Magister Manajemen Universitas Diponegoro.

Sabur Mollah, Omar Al Farooque, Wares Karim (2012), "Ownership structure, corporate governance, and firm performance Evidence form an Africanemerging market", Studies in Economics and finance, 29 (4), 301-319.

Salman, A. K., \& Yazdanfar, D. (2012). "Profitability in Swedish Micro Firms: a Quantile Regression Approach" , International Business Research, 5 (8), 94-106.

Sarwono, Jonathan (2006). Metode Penelitian Kuantitatif dan Kualitatif, Yogyakarta, Graha Ilmu.

Sekaredi, Sawitri (2011). "Pengaruh Corporate Governance Terhadap Kinerja Keuangan Perusahaan (Studi pada Perusahaan yang Terdaftar di LQ45 Tahun 2005-2009), Undergraduate Tesis (unpublished). Thesis, Universitas Diponegoro.

Sofyaningsih, Sri dan Pancawati Hardiningsih. (2011).”Struktur Kepemilikan, Kebijakan Dividen, Kebijakan Utang Dan Nilai Perusahaan Ownership Structure, Dividend Policy And Debt Policy And Firm Value”. Jurnal Dinamika Keuangan Dan Perbankan, 3 (1), 68 - 87.

Surat Edaran Nomor SE-03/BL/2011 tentang Pedoman Penyajian dan Pengungkapan Laporan Keuangan Emiten atau Perusahaan Publik.

Tumpal Manik (2011). "Analisis pengaruh kepemilikan manajemen, komisaris independen, komite audit, umur perusahaan terhadap kinerja keuangan" JEMI, 2, (2), Desember, 25-36.

Xie, B.,Davidson, W.N dan Dadalt P. J (2003) "Earnings Management and Corporate Governance: The Role of The Board and The Audit Committee, Journal of Corporate Finance, 9, 295-316. 